\title{
Sorption isotherms and their fitted equations for dried chips of cassava roots (Manihot Esculenta Crantz; Tme-7 variety) and the resulting isosteric heats of sorption
}

\author{
${ }^{1,{ }^{*}}$ Ajala, A.S., ${ }^{2}$ Ngoddy, P.O. and ${ }^{1}$ Olajide, J.O. \\ ${ }^{I}$ Department of Food Science and Engineering, Ladoke Akintola University of Technology, P.M.B. 4000, \\ Ogbomoso, Nigeria \\ ${ }^{2}$ Department of Food Science and Technology, University of Nigeria, Nsukka, Enugu, Nigeria
}

\begin{abstract}
Article history:
Received: 9 November 2019 Received in revised form: 13 December 2019

Accepted: 14 December 2019 Available Online: 17 January 2020
\end{abstract}

\section{Keywords:}

Cassava chips,

Models,

Sorption-isotherms,

Isosteric heat

\section{DOI:}

https://doi.org/10.26656/fr.2017.4(3).340

\begin{abstract}
Cassava roots are susceptible to deterioration with $24 \mathrm{hrs}$ of harvest; it needs processing into a more stable material such as dried cassava chips to extend its shelf life for long storage. However, improper knowledge of the effect of atmospheric relative humidity on these dried chips during storage makes it mouldy and unacceptable. This work aimed at studying the effect of sorption isotherms on the dried cassava chips. In this study, adsorption and desorption isotherm were carried out using static gravimetric method and data for equilibrium moisture content (EMC) were generated at five (5) temperatures (53, $60,70,80,86^{\circ} \mathrm{C}$ ). These were fitted into four (4) isotherm-models [Oswin, Peleg, the Modified Oswin and GAB]. The statistical criteria to test the models were coefficient of determination $\left(\mathrm{R}^{2}\right)$, reduced chi-square $\left(\chi^{2}\right)$, root mean square error (RMSE) and mean bias error (MBE). The values of EMC ranged from 7.21-12.44\% wb. The values of $\mathrm{R}^{2}$ ranged from 0.95-0.99; $\chi^{2}$ ranged from 0.008-0.14; RMSE values ranged from 0.06-0.254 while MBE values ranged from -0.0004-1.1E-5. The values of isosteric heat of sorption calculated from the isosteres recorded a range from 6.579 to $67.829 \mathrm{~kJ} / \mathrm{mole}$. The Pelegmodel gave the best fit in the relative humidity range of 10 to $80 \%$. The values of EMC show that the chips can have a stable shelf life without spoilage.
\end{abstract}

\section{Introduction}

Nigeria is the world's largest producer of cassava (FAO-STAT, 2012; MAFAP, 2013) and has a defined national policy to aggressively expand its production and processing for the economic development of the country. The production and processing are crucial due to its perishable nature after harvest. Therefore, it is quickly processed into domestic food materials such as 'gari', 'lafun' and 'fufu'. However, in international trade, cassava chip is a major way by which cassava is being sold. It is a semi-raw material for the production of alcohol, citric acid and starch. The local demand for chips is at an alarming rate because feed composers have discovered that cassava chips provide an excellent source of carbohydrate. The European animal feed industries are demanding for cassava chips in large quantities of more than 7 million tonnes in 2000. By 2012, China alone demanded more than 1 million tonnes (NIRSAL and FMARD, 2012). The life span of cassava chips is adjudged to be six months and the long-distance covered during exportation of these chips is a crucial factor as large part of the export turns mouldy on the high sea. This is because cassava chip is hygroscopic and gains moisture over time. This causes losses to the quality of chips more than any other means as it induces microbial and chemical reactions in the chips which affect colour and downgrade the chips. Therefore it is important to consider and study the water activity of the chips. This is a determinant factor of stability of the chips in long term storage because there is a possibility that the chips experience increase in moisture (adsorption) or decrease in moisture (desorption) due to fluctuations in relative humidity. Therefore study of adsorption and desorption isotherm or their models which define the relationship between water activity and equilibrium moisture content (EMC) at different temperatures are important for three reasons: (a) to define the extent of free water removable in hot air drying of the chips which is all the moisture above the EMC, (b) to define the water activity at EMC and ensure it is low enough to ensure long term stability in storage and (c), to provide a basis for calculating the energy (isosteric heat) profile required for drying in a 
piece of equipment to be designed and operated for the purpose. These reasons form the basis of the study.

\section{Materials and methods}

\subsection{Material}

Mature cassava roots (Manihot esculenta Crantz) TME 7 variety that was free from defects were used. They were obtained from the Ladoke Akintola University of Technology Teaching and Research Farm Ogbomoso, Nigeria. The moisture content of the roots determined using AOAC (2005) method was 75\% (wet basis).

\subsubsection{Water and reagents}

Concentrated sulphuric acids (Tetraoxosulphate VI acid) of analytical grade was formulated at predetermined concentrations by dilution with distilled water establish relative humidity values $(\mathrm{RH}-10,20,30$, $40,50,60,70$ and $80 \%$ ) employed in the experiments

\subsubsection{Equipment}

Chips dices were made manually with a sharp stainless steel knife and were loaded into the moisture test pan as samples. Glass desiccators with their lids sealed carefully by applying a film of Vaseline fat were used to hold the samples in the test pans over the solution of sulphuric acid which at each constant temperature generated the predetermined environmental RH\% required. A Genalb (England) incubator Model (M75CPD) was used to hold the desiccators and content at each predetermined constant temperature at a time. Colour Instrument (colour tech PCM, made in US, patent 5137364) was used to determine the colour of the chips. A laboratory tunnel dryer in the pilot plant of the Department of Food Science and Engineering, LAUTECH was used to dry the chips

\subsection{Methods}

\subsubsection{Drying of cassava chips}

The chips were produced from cassava roots using the method of FIIRO (2006). The cassava roots were peeled and diced with stainless steel knives into dimensions: $5 \mathrm{~cm} \times 1 \mathrm{~cm} \times 0.1 \mathrm{~cm}$. The chips were dried down to a moisture content of $14 \%$ using the tunnel dryer (Ashaye et al., 2005). The chips were thereafter cooled and packaged into polythene bags and stored under moisture-tight conditions until they were used for the generation of adsorption and desorption isotherms.

\section{(a) Determination of sorption isotherms}

The static gravimetric method was used (Paulo et al., 2010). Three replicates of each sample of the cassava chips (10 g) were weighed into moisture test pans in desiccators at each humidity point and temperature level (Ajibola, 1986). Each desiccator was maintained at one relative humidity (rh) value between 10 and $80 \%$. The desiccators were then placed in the Genalb incubator to maintain the required temperature level $(53,60,70,80$ and $86^{\circ} \mathrm{C}$ ). Samples for adsorption and desorption were monitored till equilibration by cooling and weighing at intervals until a constant weight was attained. The time taken for the experiments was four weeks. Equilibrium moisture content (EMC) values were found by calculation (Igbeka et al., 1975; Oyelade et al., 2001; Falade et al., 2003).

\section{(b) Determination of isosteric heat of sorption}

Isosteric heat of sorption $\left(\mathrm{Q}_{\mathrm{st}}\right)$ for experimental temperature range explored was calculated from the Clausius-Clayperon Equation as written in Equation1

$$
Q_{s t}=R\left[\frac{T_{1} T_{2}}{T_{2}-T_{1}} \ln \left(a_{w}\right)\right]
$$

where: $T_{1}$ and $T_{2}$ are the absolute temperature range of study $\left({ }^{\circ} \mathrm{K}\right), \mathrm{a}_{\mathrm{w}}$ is the water activity and $\mathrm{R}$ is the universal gas constant $(8.314 \mathrm{~J} / \mathrm{mol} \mathrm{K})$.

\section{(c) Isotherm equations and modeling}

Four widely tested model equations were fitted to the experimental data. The models are Guggenheim and Anderson and de Boer (GAB), Oswin, modified Oswin and Peleg. The experimental data were fitted into each of the models and the model that best described the isotherm data was selected. The models were evaluated using four parameters namely: the coefficient of determination $\left(\mathrm{R}^{2}\right)$, reduced chi-square $\left(\chi^{2}\right)$, root mean square error (RMSE) and mean bias error (MBE). Mathematical expressions of the models are as shown in Table 1.

\section{(d) Statistical analysis}

Subscripted constants for each model were estimated using a non-linear regression analysis performed using Statistical Package for the Social Scientist (SPSS-15.0 versions) software. Statistical criteria viz; the coefficient of determination $\left(\mathrm{R}^{2}\right)$, reduced chi-square $\left(\chi^{2}\right)$, root mean square error (RMSE) and mean bias error (MBE) were applied to test the reliability of each model. A good fit is said to occur between experimental and predicted values of a model when $\mathrm{R}^{2}$ is high; and $\chi^{2}, \mathrm{RMSE}$ and MBE are low (Demir et al., 2004). The RMSE represent the deviation between the predicted and experimental values and it is required to approach zero (Gökhan et al., 2009). The comparison criteria calculated using equations 2,3 and 4: 
Table 1. Mathematical sorption models

\begin{tabular}{clc}
\hline \multicolumn{1}{c}{ Models } & \multicolumn{1}{c}{ Equation } & References \\
\hline Oswin & $X_{e}=k_{1}\left(a_{w} /\left(1-a_{w}\right)\right)^{c_{1}}$ & Maroulis and Saravacos $(2002)$ \\
Peleg & $X_{e}=a_{2} * a_{w}^{b_{2}}+c^{*} a_{w}^{d_{2}}$ & Jirawadee et al. $(2011)$ \\
Modified Oswin & $X_{e}=\left(a_{3}+b_{3} T\right)\left(a_{w} /\left(1-a_{w}\right)\right)^{c_{3}}$ & Maroulis and Saravacos (2002) \\
GAB & $X_{e}=\frac{a_{4} b_{4} c_{4} a_{w}}{\left(1-c_{4} a_{w}\right)\left(1-c_{4} a_{w}+b_{4} c_{4} a_{w}\right)}$ & Cáceres-Huambo and Menegalli (2009)
\end{tabular}

$\mathrm{GAB}=$ Guggenheim, Anderson and De Boer; $a_{n}, b_{n}, c_{n}, d_{n}$ and $k_{n}$ are subscripted constants for each equation, $\mathrm{X}_{\mathrm{e}}=$ equilibrium moisture content $(\mathrm{db}) ; \mathrm{a}_{\mathrm{w}}=$ water activity

$$
\begin{gathered}
\chi^{2}=\sum_{i=1}^{N} \frac{\left(E M C_{(\mathrm{exp}, i)}-E M C_{(\text {pre }, i)}\right)^{2}}{N-z} \\
\mathrm{MBE}=\frac{1}{N} \sum_{i=1}^{N}\left(E M C_{(\text {pred }, i)}-E M C_{(\mathrm{exp}, i)}\right) \\
\mathrm{RMSE}=\left[\frac{1}{N} \sum_{1}^{N}\left(E M C_{(\text {pred }, i)}-E M C_{(\mathrm{exp}, i)}\right)^{2}\right]^{1 / 2}
\end{gathered}
$$

Where $E M C_{(p r e i)}=$ the i-th predicted equilibrium moisture content, $E M C_{(\exp i)}=$ the i-th experimental equilibrium moisture content, $N=$ number of observed experiments and $z=$ number of constants in the models.

Water activity values corresponding to designated relative humidity values are calculated by applying Equation 5.

$$
a_{w}=\frac{R H \%}{100}
$$

\section{Results and discussion}

\subsection{Evaluation of constants in the models}

Table 2 shows the values of constants for all the four models tested. In all the models, the constants recorded ' $a_{2}$ ' recorded the highest and lowest values of 12.63 and 1.00 , respectively which corresponding to desorption at 53 and $60^{\circ} \mathrm{C}$ calculated in the Peleg model; the constant $\mathrm{a}_{3}$ in the Modified Oswin recorded the highest and lowest values of 10.61 and 8.917 corresponding to desorption at $53^{\circ} \mathrm{C}$ and adsorption at $86^{\circ} \mathrm{C}$ respectively; also, the constant $\mathrm{a}_{4}$ in the GAB model recorded the highest and lowest values of 6.869 and -7.44 corresponding to desorption at 80 and $53^{\circ} \mathrm{C}$, respectively. The constant ' $b_{2}$ ' recorded the highest and lowest values of 2.143 and -0.978 , respectively corresponding to adsorption at $53^{\circ} \mathrm{C}$ and desorption at $60^{\circ} \mathrm{C}$ calculated for the Peleg model while constant ' $b_{4}$ ' recorded the highest and lowest values of 1.018 and 0.945 corresponding to adsorption at $53^{\circ} \mathrm{C}$ and desorption at $70^{\circ} \mathrm{C}$, respectively in the GAB model. The highest values recorded for constant ' $c_{1}$ ' is 1.00 corresponding to both adsorption at 53 and $86^{\circ} \mathrm{C}$ and likewise, desorption at $53^{\circ} \mathrm{C}$ whereas the lowest value for constant $c_{1}$ is 0.121 which corresponds to desorption at $70^{\circ} \mathrm{C}$ calculated for the Oswin model; the highest and lowest values recorded for constant ' $\mathrm{c}_{2}$ ' are 8.859 and -0.996 corresponding to adsorption at $53^{\circ} \mathrm{C}$ and desorption at $60^{\circ} \mathrm{C}$ calculated for Peleg model; the highest and lowest values recorded for constant ' $\mathrm{c}_{3}$ ' are 1.28 and 0.121 corresponding to desorption at $80^{\circ} \mathrm{C}$ and adsorption at $70^{\circ} \mathrm{C}$, respectively; the highest and lowest values for constant ' $c_{4}$ ' are 87863 and -4505 corresponding to desorption at $80^{\circ} \mathrm{C}$ and adsorption at $70^{\circ} \mathrm{C}$ respectively. The highest and lowest values recorded for constant ' $d_{2}$ ' are 0.093 and -0.99 calculated for desorption at $80^{\circ} \mathrm{C}$ and desorption at $60^{\circ} \mathrm{C}$, respectively for the Peleg model. The highest and lowest values recorded for the constant ' $\mathrm{k}_{1}$ ' are 10.28 and 0.051 , corresponding to desorption at $60^{\circ} \mathrm{C}$ and adsorption at $86^{\circ} \mathrm{C}$, respectively for the Oswin model. Values of constants presented in Table 2 show that sorption temperatures affect the constants as there are variations in recorded values for the same model. For instance, " $\mathrm{a}_{2}$ " in the Peleg model, varied from temperature to temperature between $53^{\circ} \mathrm{C}$ and $86^{\circ} \mathrm{C}$ temperatures. No discernible pattern is evident in the variations.

\subsection{Model evaluation using statistical criteria}

From Table 3, all values of $\mathrm{R}^{2}$ calculated are greater than 0.96 . These high values of $\mathrm{R}^{2}$ in all cases suggest that each of the four models gave a good fit to the experimental data. A good fit occurs when $\mathrm{R}^{2}$ is high (Ahmet et al., 2007). The highest value of $\mathrm{R}^{2}$ calculated was 0.999 recorded for the Peleg model corresponding to desorption isotherm at $53^{\circ} \mathrm{C}$. The lowest value was 0.967 calculated for the Oswin model corresponding to adsorption isotherm at $70^{\circ} \mathrm{C}$. The same $\mathrm{R}^{2}$ value of 0.967 was also recorded for the Modified Oswin model corresponding to adsorption isotherm at $70^{\circ} \mathrm{C}$. The average $\mathrm{R}^{2}$ values recorded for the models are as follows: Oswin (0.9816), Peleg (0.9966), Modified Oswin (0.9816) and GAB (0.9902). The lowest value of reduced chi-square is 0.008 corresponding to the adsorption isotherm at $60^{\circ} \mathrm{C}$ for the Peleg model. The highest value is 0.1489 corresponding to the adsorption isotherm at $53^{\circ} \mathrm{C}$ for the Modified Oswin model. The average value of the reduced chi-square was 0.0434 for all models; however, the average reduced chi-square 
Table 2. Values for model constants

\begin{tabular}{|c|c|c|c|c|c|}
\hline \multirow[t]{2}{*}{ Model } & \multirow[t]{2}{*}{ Water Activity } & \multicolumn{3}{|c|}{ Constants } & \multirow[b]{2}{*}{$\mathrm{K}_{1}$} \\
\hline & & $\mathrm{C}_{1}$ & & & \\
\hline \multirow[t]{11}{*}{ Oswin } & Adsorption at $53^{\circ} \mathrm{C}$ & 1 & & & -0.032 \\
\hline & Adsorption at $60^{\circ} \mathrm{C}$ & 0.128 & & & 9.86 \\
\hline & Adsorption at $70^{\circ} \mathrm{C}$ & 0.131 & & & 9.505 \\
\hline & Adsorption at $80^{\circ} \mathrm{C}$ & 0.135 & & & 9.143 \\
\hline & Adsorption at $86^{\circ} \mathrm{C}$ & 1 & & & -0.051 \\
\hline & Desorption at $53^{\circ} \mathrm{C}$ & 1 & & & -0.03 \\
\hline & Desorption at $60^{\circ} \mathrm{C}$ & 0.129 & & & 10.28 \\
\hline & Desorption at $70^{\circ} \mathrm{C}$ & 0.121 & & & 9.846 \\
\hline & Desorption at $80^{\circ} \mathrm{C}$ & 0.122 & & & -0.014 \\
\hline & Desorption at $86^{\circ} \mathrm{C}$ & 0.127 & & & 9.263 \\
\hline & & $\mathrm{a}_{2}$ & $\mathrm{~b}_{2}$ & $\mathrm{c}_{2}$ & $\mathrm{~d}_{2}$ \\
\hline \multirow[t]{11}{*}{ Peleg } & Adsorption at $53^{\circ} \mathrm{C}$ & 5.769 & 2.143 & 8.859 & 0.045 \\
\hline & Adsorption at $60^{\circ} \mathrm{C}$ & 5.045 & 1.919 & 8.715 & 0.054 \\
\hline & Adsorption at $70^{\circ} \mathrm{C}$ & 6.266 & 1.546 & 7.094 & -0.02 \\
\hline & Adsorption at $80^{\circ} \mathrm{C}$ & 5.707 & 1.552 & 7.104 & 0.005 \\
\hline & Adsorption at $86^{\circ} \mathrm{C}$ & 5.475 & 2.066 & 7.646 & 0.043 \\
\hline & Desorption at $53^{\circ} \mathrm{C}$ & 12.63 & 0.419 & 0.878 & -0.57 \\
\hline & Desorption at $60^{\circ} \mathrm{C}$ & 1 & -0.978 & -0.996 & -0.99 \\
\hline & Desorption at $70^{\circ} \mathrm{C}$ & 5.852 & 0.873 & 6.673 & -0.01 \\
\hline & Desorption at $80^{\circ} \mathrm{C}$ & 3.47 & 1.068 & 8.566 & 0.093 \\
\hline & Desorption at $86^{\circ} \mathrm{C}$ & 4.812 & 0.958 & 7.064 & 0.038 \\
\hline & & $\mathrm{a}_{3}$ & $\mathrm{~b}_{3}$ & & $\mathrm{c}_{3}$ \\
\hline Modified & Adsorption at $53^{\circ} \mathrm{C}$ & 10.1 & 0 & & 0.131 \\
\hline \multirow[t]{10}{*}{ Oswin } & Adsorption at $60^{\circ} \mathrm{C}$ & 9.86 & 0 & & 1.28 \\
\hline & Adsorption at $70^{\circ} \mathrm{C}$ & 9.505 & 0 & & 0.131 \\
\hline & Adsorption at $80^{\circ} \mathrm{C}$ & 9.143 & 0 & & 0.135 \\
\hline & Adsorption at $86^{\circ} \mathrm{C}$ & 8.917 & 0 & & 0.14 \\
\hline & Desorption at $53^{\circ} \mathrm{C}$ & 10.61 & 0 & & 0.13 \\
\hline & Desorption at $60^{\circ} \mathrm{C}$ & 10.27 & 0 & & 0.129 \\
\hline & Desorption at $70^{\circ} \mathrm{C}$ & 9.846 & 0 & & 0.121 \\
\hline & Desorption at $80^{\circ} \mathrm{C}$ & 9.562 & 0 & & 0.122 \\
\hline & Desorption at $86^{\circ} \mathrm{C}$ & 9.236 & 0 & & 0.127 \\
\hline & & $\mathrm{a}_{4}$ & $\mathrm{~b}_{4}$ & & $\mathrm{C}_{4}$ \\
\hline \multirow[t]{10}{*}{$\overline{\mathrm{GAB}}$} & Adsorption at $53^{\circ} \mathrm{C}$ & -6.02 & 1.018 & & 64.81 \\
\hline & Adsorption at $60^{\circ} \mathrm{C}$ & 6.277 & 1.011 & & 96.01 \\
\hline & Adsorption at $70^{\circ} \mathrm{C}$ & 6.695 & 1 & & -4505 \\
\hline & Adsorption at $80^{\circ} \mathrm{C}$ & 1 & 0.974 & & -0.943 \\
\hline & Adsorption at $86^{\circ} \mathrm{C}$ & 1 & 0.977 & & -0.943 \\
\hline & Desorption at $53^{\circ} \mathrm{C}$ & -7.44 & 1 & & 20692 \\
\hline & Desorption at $60^{\circ} \mathrm{C}$ & 1 & 0.948 & & -0.947 \\
\hline & Desorption at $70^{\circ} \mathrm{C}$ & 1 & 0.945 & & -0.944 \\
\hline & Desorption at $80^{\circ} \mathrm{C}$ & 6.869 & 1 & & 87863 \\
\hline & Desorption at $86^{\circ} \mathrm{C}$ & 6.555 & 1 & & 21410 \\
\hline
\end{tabular}

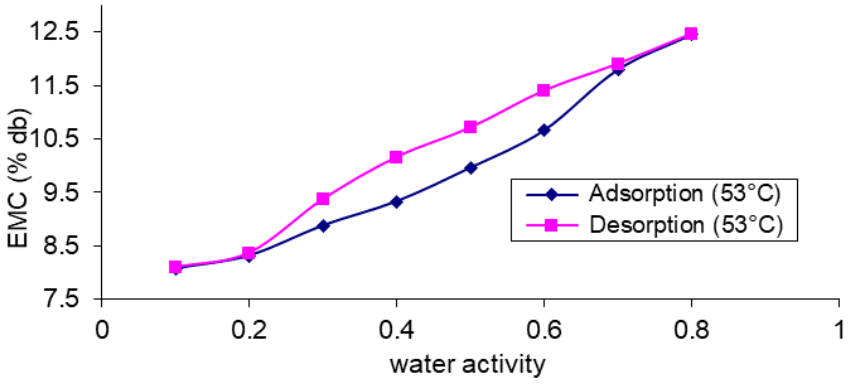

Figure 1. Hysteresis plot of dried cassava chips at $53^{\circ} \mathrm{C}$

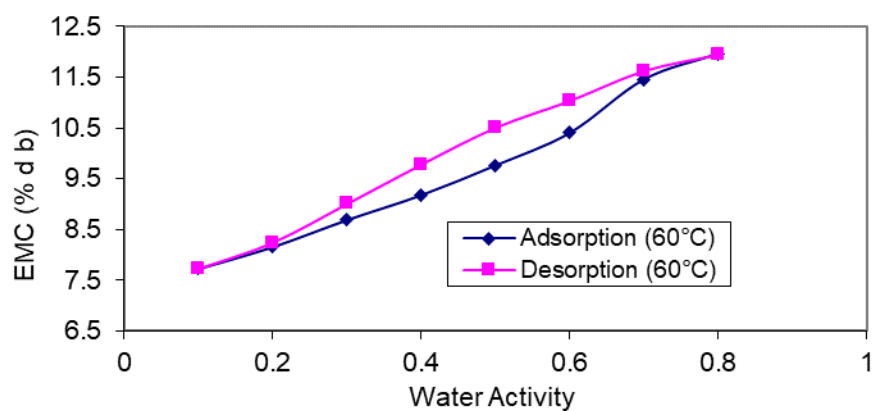

Figure 2. Hysteresis plot of dried cassava chips at $60^{\circ} \mathrm{C}$ 


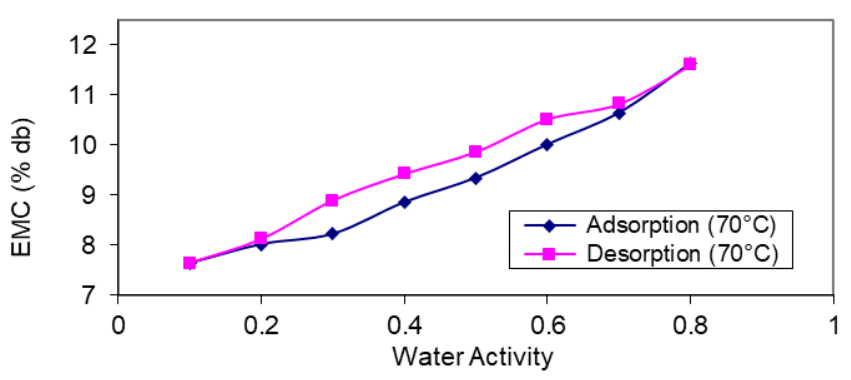

Figure 3. Hysteresis plot of dried cassava chips at $70^{\circ} \mathrm{C}$

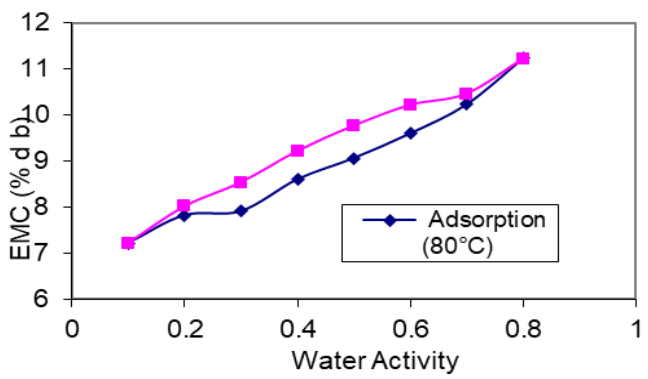

Figure 4. Hysteresis plot of dried cassava chips at $80^{\circ} \mathrm{C}$

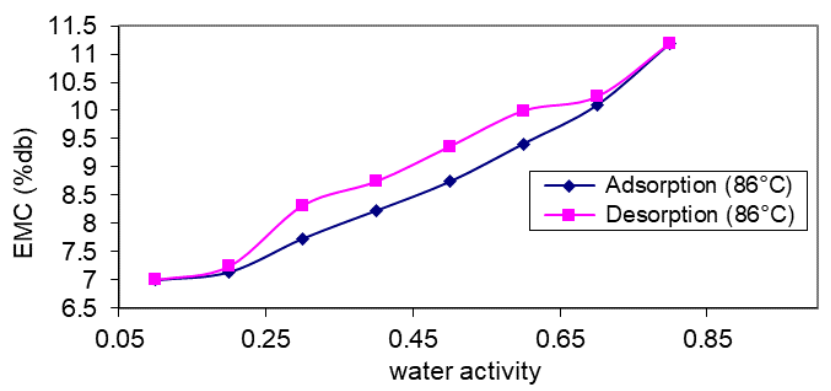

Figure 5. Hysteresis plot of dried cassava chips at $86^{\circ} \mathrm{C}$

Table 3. Values of the statistical criteria calculate for the models

\begin{tabular}{|c|c|c|c|c|c|}
\hline Model & Water Act. & $\mathrm{R}^{2}$ & $\chi^{2}$ & RMSE & MBE \\
\hline \multirow[t]{10}{*}{ Oswin } & Adsorption at $53^{\circ} \mathrm{C}$ & 0.969 & 0.0815 & 0.2472 & -0.0015 \\
\hline & Adsorption at $60^{\circ} \mathrm{C}$ & 0.984 & 0.0429 & 0.1794 & -0.0016 \\
\hline & Adsorption at $70^{\circ} \mathrm{C}$ & 0.967 & 0.0854 & 0.2532 & -0.0024 \\
\hline & Adsorption at $80^{\circ} \mathrm{C}$ & 0.977 & 0.0592 & 0.2104 & -0.0022 \\
\hline & Adsorption at $86^{\circ} \mathrm{C}$ & 0.973 & 0.0749 & 0.2371 & -0.0029 \\
\hline & Desorption at $53^{\circ} \mathrm{C}$ & 0.99 & 0.0246 & 0.16969 & -0.0198 \\
\hline & Desorption at $60^{\circ} \mathrm{C}$ & 0.982 & 0.0159 & 0.13287 & 0.0267 \\
\hline & Desorption at $70^{\circ} \mathrm{C}$ & 0.993 & 0.0156 & 0.1904 & -0.0931 \\
\hline & Desorption at $80^{\circ} \mathrm{C}$ & 0.989 & 0.0228 & 0.1584 & -0.0223 \\
\hline & Desorption at $86^{\circ} \mathrm{C}$ & 0.992 & 0.0172 & 0.1182 & -0.0502 \\
\hline \multirow[t]{10}{*}{ Peleg } & Adsorption at $53^{\circ} \mathrm{C}$ & 0.995 & 0.0222 & 0.1055 & -0.0003 \\
\hline & Adsorption at $60^{\circ} \mathrm{C}$ & 0.998 & 0.0081 & 0.0639 & -0.0016 \\
\hline & Adsorption at $70^{\circ} \mathrm{C}$ & 0.998 & 0.0095 & 0.0689 & $1.10 \mathrm{E}-05$ \\
\hline & Adsorption at $80^{\circ} \mathrm{C}$ & 0.995 & 0.0199 & 0.0998 & -0.001 \\
\hline & Adsorption at $86^{\circ} \mathrm{C}$ & 0.998 & 0.0087 & 0.066 & 0.0021 \\
\hline & Desorption at $53^{\circ} \mathrm{C}$ & 0.999 & 0.0169 & 0.1956 & -0.0198 \\
\hline & Desorption at $60^{\circ} \mathrm{C}$ & 0.997 & 0.0463 & 0.1791 & 0.0267 \\
\hline & Desorption at $70^{\circ} \mathrm{C}$ & 0.995 & 0.0155 & 0.1988 & -0.0956 \\
\hline & Desorption at $80^{\circ} \mathrm{C}$ & 0.995 & 0.0165 & 0.1909 & -0.0223 \\
\hline & Desorption at $86^{\circ} \mathrm{C}$ & 0.996 & 0.0115 & 0.1291 & 0.0514 \\
\hline Modified & Adsorption at $53^{\circ} \mathrm{C}$ & 0.969 & 0.1489 & 0.2729 & -0.0015 \\
\hline \multirow[t]{9}{*}{ Oswin } & Adsorption at $60^{\circ} \mathrm{C}$ & 0.984 & 0.0643 & 0.1794 & -0.0016 \\
\hline & Adsorption at $70^{\circ} \mathrm{C}$ & 0.967 & 0.0128 & 0.2532 & -0.0024 \\
\hline & Adsorption at $80^{\circ} \mathrm{C}$ & 0.977 & 0.0889 & 0.2108 & -0.0022 \\
\hline & Adsorption at $86^{\circ} \mathrm{C}$ & 0.973 & 0.1124 & 0.2371 & -0.0029 \\
\hline & Desorption at $53^{\circ} \mathrm{C}$ & 0.99 & 0.0369 & 0.1696 & -0.0198 \\
\hline & Desorption at $60^{\circ} \mathrm{C}$ & 0.982 & 0.0233 & 0.1328 & 0.0267 \\
\hline & Desorption at $70^{\circ} \mathrm{C}$ & 0.993 & 0.0233 & 0.1904 & -0.0931 \\
\hline & Desorption at $80^{\circ} \mathrm{C}$ & 0.989 & 0.0342 & 0.1584 & -0.0223 \\
\hline & Desorption at $86^{\circ} \mathrm{C}$ & 0.992 & 0.0258 & 0.1182 & 0.0502 \\
\hline \multirow[t]{10}{*}{ GAB } & Adsorption at $53^{\circ} \mathrm{C}$ & 0.987 & 0.0595 & 0.1929 & -0.0015 \\
\hline & Adsorption at $60^{\circ} \mathrm{C}$ & 0.994 & 0.0265 & 0.1287 & 0.0008 \\
\hline & Adsorption at $70^{\circ} \mathrm{C}$ & 0.973 & 0.1034 & 0.2542 & $1.10 \mathrm{E}-05$ \\
\hline & Adsorption at $80^{\circ} \mathrm{C}$ & 0.993 & 0.0277 & 0.1317 & -0.001 \\
\hline & Adsorption at $86^{\circ} \mathrm{C}$ & 0.99 & 0.0394 & 0.1571 & -0.0004 \\
\hline & Desorption at $53^{\circ} \mathrm{C}$ & 0.997 & 0.06 & 0.1565 & -0.0211 \\
\hline & Desorption at $60^{\circ} \mathrm{C}$ & 0.992 & 0.0787 & 0.0948 & 0.0229 \\
\hline & Desorption at $70^{\circ} \mathrm{C}$ & 0.994 & 0.0683 & 0.1813 & -0.0956 \\
\hline & Desorption at $80^{\circ} \mathrm{C}$ & 0.988 & 0.0158 & 0.1558 & -0.0236 \\
\hline & Desorption at $86^{\circ} \mathrm{C}$ & 0.994 & 0.0729 & 0.096 & 0.0527 \\
\hline
\end{tabular}


value recorded for each model is as follows: Oswin (0.0440), Peleg (0.0175), Modified Oswin (0.0171) and GAB (0.0552). The lowest value of the root mean square error (RMSE) recorded is 0.0639 corresponding to the adsorption isotherm at $60^{\circ} \mathrm{C}$ in the Peleg model. The highest value recorded occurred in Modified Oswin model with a value of 0.2729 (adsorption at $53^{\circ} \mathrm{C}$ ). The overall average value of RMSE in all models is 0.1666 ; while the average in each model for Oswin, Peleg, Modified Oswin and GAB are 0.1897, 0.1298, 0.1923 and 0.1549 , respectively. The average value of mean bias error (MBE) for the four models is recorded as -0.00913 . The lowest value of MBE recorded is -0.0956 found at $70^{\circ} \mathrm{C}$ for desorption for the Peleg model, while the highest MBE value recorded is 0.0527 corresponding to $86^{\circ} \mathrm{C}$ for desorption in the GAB model. The average MBE value recorded for each of the models is as follows: Oswin (-0.0169), Peleg (-0.0060), Modified Oswin (-0.0068) and GAB (-0.0067).

According to Demir et al. (2004), a good fit is said to occur between experimental and predicted values of a model when $\mathrm{R}^{2}$ is high; and the reduced chi-square $\left(\chi^{2}\right)$, mean bias error (MBE) and root mean square error (RMSE) are low. Therefore the Peleg model can be considered to be the best tested in this study to represent the sorption isotherm of cassava chips.

\subsection{Adsorption and desorption (hysteresis)} characteristics of the cassava chips

Figures 1, 2, 3, 4 and 5 are hysteresis isotherm plots for the chips at designated isotherm temperatures from $53^{\circ} \mathrm{C}$ to $86^{\circ} \mathrm{C}$. It is observed that each of hysteresis loop isotherms; in accordance with BET classification, conform to the characteristic behaviour of type II sigmoidal sorption isotherm in which the curves are concave upwards. It takes into account the existence of multilayers at material internal surfaces (Ertugay and Certel, 2000; Ricardo et al., 2011). From Figure 1, at $53^{\circ} \mathrm{C}$ the lowest EMC value of adsorption isotherms is $8.07 \%$ corresponding to $0.1 \mathrm{a}_{\mathrm{w}}$ while the highest value is $12.44 \%$ corresponding to $0.8 \mathrm{a}_{\mathrm{w}}$. Also, the lowest EMC value of desorption isotherm is $8.09 \%$ at $0.1 \mathrm{a}_{\mathrm{w}}$ while the highest value is $12.46 \%$ at $0.8 \mathrm{a}_{\mathrm{w}}$. Figure 2 presents the hysteresis loop of the cassava chips sample. The lowest adsorption EMC value at $60^{\circ} \mathrm{C}$ is $7.73 \%$ corresponding to $0.1 \mathrm{a}_{\mathrm{w}}$ while the highest value is $11.96 \%$ corresponding to $0.8 \mathrm{a}_{\mathrm{w}}$. The isotherm characteristic of cassava chips samples at $70^{\circ} \mathrm{C}$ is as presented in Figure 3. The lowest adsorption EMC value is $7.63 \%$ corresponding to $0.1 \mathrm{a}_{\mathrm{w}}$ while the highest value is $11.63 \%$ corresponding to $0.8 \mathrm{a}_{\mathrm{w}}$. In addition, the lowest EMC value for desorption isotherm is $7.64 \%$ corresponding to $0.1 \mathrm{a}_{\mathrm{w}}$ while the highest EMC value is
$7.64 \%$ corresponding to $0.8 \mathrm{a}_{\mathrm{w}}$. Figure 4 presents the isotherm properties of cassava chips samples at $80^{\circ} \mathrm{C}$. The lowest adsorption EMC value is $7.21 \%$ corresponding to $0.1 \mathrm{a}_{\mathrm{w}}$ while the highest value is $11.23 \%$ at $0.8 \mathrm{a}_{\mathrm{w}}$. Also, the lowest desorption EMC value is $7.21 \%$ corresponding to $0.1 \mathrm{a}_{\mathrm{w}}$ while the highest value is $11.22 \%$ corresponding to $0.8 \mathrm{a}_{\mathrm{w}}$. Furthermore, the lowest EMC desorption isotherm value is $7.21 \%$ while the highest value is $11.22 \%$ corresponding to $0.1 \mathrm{a}_{\mathrm{w}}$ and $0.8 \mathrm{a}_{\mathrm{w}}$, respectively. Figure 5 presents the sorption isotherm properties of cassava chips experimented at $86^{\circ} \mathrm{C}$, the lowest value of adsorption isotherm recorded is $7.00 \%$ while the highest value recorded is $11.19 \%$ corresponding to $0.1 \mathrm{a}_{\mathrm{w}}$ and $0.8 \mathrm{a}_{\mathrm{w}}$, respectively. Besides, the lowest desorption EMC isotherm value recorded is $7.00 \%$ while the highest value is $11.19 \%$ corresponding to $0.1 \mathrm{a}_{\mathrm{w}}$ and $0.8 \mathrm{a}_{\mathrm{w}}$, respectively. EMC isotherm values recorded in this study are close to values for taro flour reported by Budi and Jenshinn (2010) which ranged from $5.00-7.86 \%$ at $\mathrm{a}_{\mathrm{w}}$ ranges of $0.1-0.8$. It is comparable with the values for potato starch with an average value of $6.02 \%$ at $\mathrm{a}_{\mathrm{w}}$ ranges of $0.091-0.91$ (Francisco et al., 2011). It is also comparable with the values for cassava flour which ranged from $2.1-11.2 \%$ at $a_{\mathrm{w}}$ ranges of 0.1-0.9 (Blaise et al., 2014). The values are also comparable with those for castor bean flour which ranged from $4.77-18.91 \%$ at $\mathrm{a}_{\mathrm{w}}$ ranges of $0.37-0.87$ (André et al., 2016).

There is a direct relationship between water activity and equilibrium moisture content of the samples as shown in Figures 1-5. At lower water activity, all the samples had lower equilibrium moisture content and conversely, at higher water activity, the samples had higher equilibrium moisture content. The reason could be that at lower water activity, the moisture is tightly bound to the active sites of the food material. The bound water includes structural water (H-bound water) and monolayer water which is absorbed by the hydrophilic and polar groups of food components (polysaccharides, protein and fat). A further reason for these patterns, according to Ricardo et al. (2011), could be that the enthalpy of vapourisation at lower water activity is considerably higher than that of pure water. As water activity increased, food nutrients especially starch molecules become more mobile in the internal phase which resulted in increased adsorption of water. This is because watersugar interaction is sufficient to cause a dissociation of sugar inducing more active sorption as reported by Rangel-Marrón et al. (2011) and Johnson and Brennan (2000).

From Figures 1-5, it is observed that temperature affected the equilibrium moisture content of the samples. The higher the temperature of a sorption isotherm, the 
lower the equilibrium values of the moisture content of the sample. In both cases of adsorption and desorption, samples at $53^{\circ} \mathrm{C}$ exhibited the highest moisture content, while the isotherm at $86^{\circ} \mathrm{C}$ recorded the lowest moisture content. These results demonstrate a strong temperature dependency of sorptive behaviour with increase in temperature leading to decrease in sorption capacity. The same observation was earlier reported by Brett et al. (2009). The reason for this, according to Machhour et al. (2012) and Mennkov and Durakova (2007), is that at increased temperature, water molecules become activated to higher energy levels causing them to become less stable and to break away from the water binding sites of the food material, thus decreasing the value of the equilibrium moisture content. A further reason for this, according to Chowdhury and Das (2010), may be attributed to the reduction in the total number of binding sites for water arising from temperature-induced changes in the microstructure of the glycerol-water film matrix.

Differences between adsorption and desorption isotherms produce hysteresis loops in which the equilibrium moisture content is higher at a particular relative humidity $(\mathrm{ERH})$ for desorption than for adsorption. It is observed that temperature affects the size of the hysteresis loop because as the temperature of the isotherms increased from 53 to $86^{\circ} \mathrm{C}$, the monolayer moisture content decreased. The reason for this has been given previously by Chowdhury and Das (2010) and Mennkov and Durakova (2007) who suggested that higher temperatures reduce the number of water molecules binding at the microstructure of adsorbed (food materials).

\subsection{Isosteric heat of sorption of the cassava chips}

Figure 6 presents the isosteric heat of sorption of cassava chips. The values decreased from $67,829 \mathrm{~J} / \mathrm{mol}$ to $6,579 \mathrm{~J} / \mathrm{mol}$ as water activity increased from 0.1 to 0.8 . The values of isosteric heat of sorption in this study are greater than those reported by Machhour et al. (2012) for peppermint tea which ranged from $40,000 \mathrm{~J} / \mathrm{mol}$ to $5,000 \mathrm{~J} / \mathrm{mol}$. The values are greater than those for potato starch which ranged from $20,000 \mathrm{~J} / \mathrm{mol}$ to $5,000 \mathrm{~J} / \mathrm{mol}$ as reported by Chowdhury and Das (2010). However, the values are in close to those of cassava fufu $(78,000 \mathrm{~J} /$ $\mathrm{mol})$, soyfufu $(72,000 \mathrm{~J} / \mathrm{mol})$ and soylafun $(82,000 \mathrm{~J} /$ mol) as reported by Elizabeth et al. (2005). Machhour et al. (2012) suggested that high values of heat of sorption at low equilibrium moisture content may be attributed to the existence of highly active polar sites on the surface of the product, which when covered with water molecules form a mono-molecular layer. As moisture content further increased, heats of sorption tend toward the value for pure water, which indicates that the moisture exists in its form as a free water surface.

Heat of sorption is the energy released in the process of sorption of water vapour molecules on a surface of the adsorbent. It is a measure of the intensity of interactive forces between water vapour molecules and the adsorbent food material (Arslan and Toğrul, 2005). The moisture content at which the heat of sorption approaches the heat of vapourization of pure water is often taken as an indication of the level of binding of water in food (Sibel and Osman, 2007). Knowledge of the magnitude of heat of sorption at specific moisture content levels provides an indication of the state of sorbed water and hence a measure of the physical, chemical and microbiological stability of the food material under the given storage conditions (Paul et al., 2009). In addition, variation in heat of sorption with moisture content and its magnitude relative to the latent heat of vaporisation of pure water provides valuable data for energy consumption calculations required for the design and operation of drying equipment. It elucidates and an understanding of the extent of water-solid versus water-water interactions (McMinn and Magee, 2003).

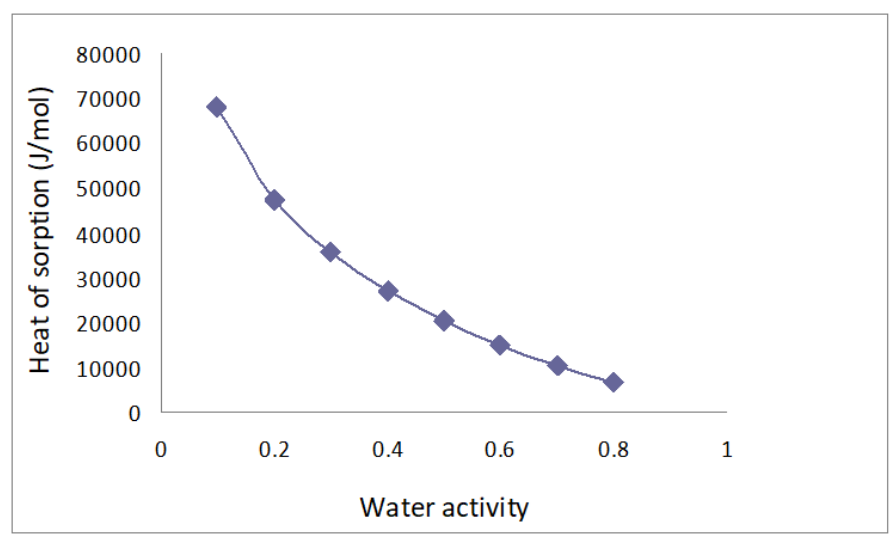

Figure 6. Isosteric heat of sorption of cassava chips

Figure 6 shows that water activity and isosteric heat of sorption are inversely related. This is because as moisture content increases, fewer active sites are available to the water molecules to bind, resulting in lower isosteric heat of sorption (Jayendra-Kumar et al., 2005). Rangel et al. (2011) observed that when moisture content increased, the available sites to suck the water are reduced, resulting in very small values of heat of sorption (Qs), giving rise to multilayer rearrangement in the structure of water and food molecules within the food sample.

Knowledge of sorption isotherms is very important not only for designing and operation of drying equipment, but also in the design of packages, prediction of quality, stability, shelf life and for calculating moisture changes that may occur during storage (Richado et al., 2011). According to Machhour et al. (2012), other applications of sorption isotherm data 
abound in respect of thermodynamic principles underlying and associated with microstructure and physical phenomena in food-water relations and in sorption kinetic studies summarized the usefulness of the sorption isotherm as three fold. First, for explaining the existences of two different classes of moisture in food materials namely bound and free moisture; secondly, for defining the phase transition at boundary between bound Elisabeth et al. (2005) and free water; thirdly, for elucidating thermodynamic phenomena associated with this boundary.

\section{Conclusion}

The Peleg equation was identified as the best model to represent sorption isotherms of cassava chips in the temperature range of 53 to $86^{\circ} \mathrm{C}$ studied. Temperature affected the equilibrium moisture content of the samples; also, water activity and isosteric heat of sorption are inversely related.

\section{Conflict of Interest}

The authors declare no conflict of interest of any sort on the project.

\section{Acknowledgment}

The author acknowledges effort of teaching staffs who read through the manuscript and technical staffs who supplied reagents in the course of this research.

\section{References}

Ahmet, C., Kamil, K. and Oktay, H. (2007). Modelling of intermittent drying of thin layer rough rice. Journal of Food Engineering, 79(1), 293-298. https://doi.org/10.1016/j.jfoodeng.2006.01.057

Ajibola, O.O. (1986). Desorption isotherm for plantain at several temperatures. Journal of Food Science, 51 (1), 169-171. https://doi.org/10.1111/j.13652621.1986.tb10862.x

André, L.D.G., Paulo, C.C., Gabriel, H.H.O., Ana, P.L.R.O. and Roberto, C.O. (2016). Moisture sorption isotherms of castor beans. Part 2: Thermodynamic properties. Revista Brasileira de Engenharia Agrícola e Ambiental, 20(8), 757-762. https://doi.org/10.1590/1807-1929/

agriambi.v20n8p757-762

AOAC. (2005). Official Methods of Analysis. 16th ed. Virginia, USA: AOAC.

Arslan, N. and Toğrul, H. (2005). Moisture sorption isotherms for crushed chillies. Biosystems Engineering, 90(1), 47-61. https://doi.org/10.1016/ j.biosystemseng.2004.10.008
Ashaye, O.A., Adegbulugbe, T.A. and Dawodu, O.J (2005). Evaluation of the processing technologies of cassava chips and flour in Oyo and Ogun States of Nigeria. World Journal of Agricultural Sciences, 1 (1), 56-58.

Blaise, K.K., Paul, M.E.K., Prosper, G. and Siaka, T. (2014). Thermodynamic analysis of sorption isotherms of cassava (Manihot esculenta). Journal of Food Science and Technology, 51(9), 1711-1723. https://doi.org/10.1007/s13197-012-0687-y

Brett, B., Figueroa M., Sandoval, A.J. and Barreiro, J.A. (2009). Moisture sorption characteristics of starchy products: oat flour and rice flour. Food Biophysics, 4, 151-157. https://doi.org/10.1007/s11483-0099112-0

Budi, N. and Jenshinn, L. (2010). Moisture sorption isotherm characteristics of taro flour. World Journal of Dairy and Food Sciences, 5(1), 1-6

Cáceres-Huambo, B.N. and Menegalli, F.C. (2009). Simulation and optimization of semi-continuous industrial tunnel dryers for fruits. Drying Technology, 27(3), 428-436. https:// doi.org/10.1080/07373930802683559

NIRSAL (The Nigeria Incentive Based Risk Sharing System for Agricultural Lending) Market Access Desk and FMARD (Federal Ministry of Agriculture and Rural Development). (2012). Nigeria Cassava Chip Export, 2012 China Term Sheet and Transaction Opportunity Brief. Nigeria: Central Bank of Nigeria, NIRSAL and Federal Ministry of Agriculture and Rural Development.

Chowdhury, T. and Das, M. (2010). Moisture sorption isotherm and isosteric heat of sorption characteristics of starch based edible films containing antimicrobial preservative. International Food Research Journal, 17, 601-614

Demir, V., Gunhan, T., Yagcioglu, A.K. and Degirmencioglu, A. (2004). Mathematical modeling and the determination of some quality parameters of air dried bay leaves. Biosystems Engineering, 88(3), 429-437. https://doi.org/10.1016/ j.biosystemseng.2004.04.005

Elisabeth, J.Q., Anton, J.B., Wilko, K.P. and Gerrit, S. (2005). Sorption isotherms, GAB parameters and isosteric heat of sorption. Journal of the Science of Food and Agriculture, 85(11), 1805-1814. https:// doi.org/10.1002/jsfa.2140

Ertugay, M.F. and Certel, M. (2000). Moisture sorption isotherms of cereals at different temperatures. Nahrung, 44(2), 107-109. https://doi.org/10.1002/ (SICI)1521-3803(20000301)44:2<107::AIDFOOD107>3.0.CO;2-F 
Falade, K.O., Adedeji, A.A. and Akingbala, J.O. (2003). Effect of soybean substitute for cowpea on textural, chemical and sorption properties of akara Ogbomoso. European Research Technology, 217(6), 492-497. https://doi.org/10.1007/s00217-003-0776-2

FAO-STAT (2012). Food and Agriculture Organization of the United Nations. Report on cassava production in the world. Rome: FAO.

FIIRO (Federal Institute of Industrial Research Oshodi). (2006). Annual Report. Lagos, Nigeria: FIIRO.

Francisco, C., Ramón, M., Diego, M.P. and Maria, D.T. (2011). Desorption Isotherms and Net Isosteric Heat of Chestnut Flour and Starch. Food and Bioprocess Technology, 4(8), 1497-1504. https:// doi.org/10.1007/s11947-009-0239-2

Gökhan, G., Necdet, Ö. and Ali, G. (2009). Solar tunnel drying characteristics and mathematical modeling of tomato. Journal of Thermal Science and Technology, 29(1), 15-23

Igbeka, J.C., Blaisdell, J.L., Herum, F.L. and Hamdy, M.Y. (1975). Equilibrium moisture content of cassava and potato. America Society of Agricultural Engineers, 75-6527.

Jayendra-Kumar, A., Singh, R.R.B., Patil, G.R. and Patel, A.A. (2005). Effect of temperature on moisture desorption isotherms of kheer. Food Science and Technology, 38(3), 303-310. https://doi.org/10.1016/ j.lwt.2003.10.009

Jirawadee, S., Amporn, S. and Panuwat, S. (2011). Moisture sorption isotherm and texture of glassy tapioca-flour-based baked products presented at 12th ASEAN Food Conference 2011, Jun 16-18 2011. Bangkok, Thailand: Food Science and Technology Association of Thailand (FoSTAT).

Johnson, P.N.T. and Brennan, J.G. (2000). Moisture sorption isotherm characteristics of plantain (Musa, AAB). Journal of Food Engineering, 44(2), 79-84. https://doi.org/10.1016/S0260-8774(99)00168-5

Machhour, H., Idlimam, A., Mahrouz, M., El Hadrami, I. and Kouhila, M. (2012). Sorption isotherms and thermodynamic properties of peppermint tea (Mentha-piperita) after thermal and biochemical treatment. Journal of Materials and Environmental Science, 3(2), 232-247.

Maroulis Z.B. and Saravacos G.D. (2002). Modelling, simulation and design of drying processes. Proceedings of the 13th International Drying Symposium, Beijing, China, August 27-30, 2002. Beijing, China: Beijing University of Chemical Technology.

McMinn, W.A.M. and Magee, T.R.A. (2003). Thermodynamic properties of moisture sorption of potato. Journal of Food Engineering, 60(2), 155157. https://doi.org/10.1016/S0260-8774(03)00036-0

Mennkov, N.D. and Durakova, A.G. (2007). Moisture sorption isotherm of sesame flour. Food Technology and Biotechnology, 45(1), 96-100.

MAFAP (Monitoring African Food and Agricultural Policies). (2013). Analysis of incentives and disincentives for cassava in Nigeria, a technical report. Rome: FAO.

Oyelade, O.J., Igbeka, J.C. and Aworh, O.C. (2001). Moisture isotherms of cowpea flour at $30^{\circ} \mathrm{C}$ and $40^{\circ} \mathrm{C}$. Journal of Applied Sciences, 4, 1700-1711

Paul, M., Carine, M., Claude, D., Thaddée, M. and François, B. (2009). Influence of drying temperature on functional properties of wet-milled starch granules. Carbohydrate Polymers, 75(2), 299-306. https://doi.org/10.1016/j.carbpol.2008.07.027

Paulo, C.C., Andre', L.D.G., Paulo, C.A.J. Gabriel, H.H.O. and Domingos, S.M.V. (2010). Moisture sorption isotherms and isosteric heat of sorption of coffee in different processing levels. International Journal of Food Science and Technology, 45(10), 2016-2022. https://doi.org/10.1111/j.13652621.2010.02373.x

Rangel-Marrón, M., Welti-Chanes, J., Córdova-Quiroz, A.V., Cerón-Bretón J.G., Cerón-Bretón R.M. and Anguebes-Franseschi, F. (2011). Estimation of moisture sorption isotherms of mango pulp freezedried. International Journal of Biology and Biomedical Engineering, 1(5),18-23.

Richado, D.A.P., Roberto, L.M. and Carmen, E.P.C. (2011). Models of sorption isotherms for food: uses and limitations. Vitae, 18(3), 325-334.

Sibel, T. and Osman, D. (2007). Thermodynamic properties and moisture adsorption isotherms of cottonseed protein isolate and different forms of cottonseed samples. Journal of Food Engineering, 81(1), 133-143. https://doi.org/10.1016/ j.jfoodeng.2006.10.015 